高強度ジャンプエクササイズ後の回復過程：

筋肉痛とパフォーマンスとの関連に焦点を当てて

尾縣 貢 $^{1}$, 木越 清信 ${ }^{1}$, 遠藤 俊典 $^{2}$, 森 健一 ${ }^{3}$

\title{
Recovery process after intensive jump exercise : focusing on the relationship between muscle soreness and performance
}

\author{
Mitsugi Ogata ${ }^{1}$, Kiyonobu Kigoshi ${ }^{1}$, Toshinori Endo ${ }^{2}$ and Kenichi Mori ${ }^{3}$ \\ 1 筑波大学, 305-8577 茨城県つくば市天王台 1-1-1 (University of Tsukuba, 1-1-1 Tennodai, Tsukuba, Ibaraki 305-8577, \\ Japan) \\ 2 青山学院大学， =252-5258 神奈川県相模原市中央区淵野辺5-10-1 (Aoyama Gakuin University, 5-10-1 Fuchinohe, Chuo- \\ ku, Sagamihara, Kanagawa 252-5258, Japan) \\ 3 武蔵大学, $=176-8534$ 東京都練馬区豊玉上1-26-1 (Musashi University, 1-26-1 Toyotamaue, Nerima-ku, Tokyo 176-8534, \\ Japan)
}

Received: April 28, 2014 / Accepted: September 18, 2014

\begin{abstract}
Purpose of this study was to examine the recovery process of delayed onset muscle soreness, jump performance, force to contact with the ground and lower limbs movement after intensive jump exercise (IJE), and the relationships between muscle soreness, changes of jump performance and lower limbs movement. Nine males who have experience in special jump exercise participated in this study voluntarily. For the measurement, subjective investigation of the muscle soreness, drop jump performance using a $30 \mathrm{~cm}$ high box [jump height, contact time and drop jump index (jump height / contact time)], ground reaction force and movements of lower limbs. This measurement was carried out before IJE (Pre), and at 4 hours (P4), 24 hours (P24) and 72 hours (P72) after IJE. Main results are as follows; at the time of P24 when intense muscle soreness appeared, significant jump height decreases and contact time increases were shown, and the jump index decreased markedly. This decrease of performance correlated to the change of knee and ankle joint movements during the eccentric phase. At P4, for a subject who felt strong muscle soreness, the decrease of jump height and jump index were considerable. At P72, most subjects recovered to the levels of jump height and contact time to the Pre level. The findings reveal that the jump performances are related to the degree of delayed onset muscle soreness.
\end{abstract}

Jpn J Phys Fitness Sports Med, 64(1): 117-124 (2015)

Keywords : intensive jump exercise, recovery, muscle soreness, kinetics, kinematics

\section{緒言}

レジスタンストレーニングの現場には, “No pain, No gain”という言葉に表されるように，実施後の筋肉痛が 生じなければ筋肥大の効果は無いという経験則がある1). また，トレーニング後の筋肉痛を指標にトレーニング計 画を作成したり，トレーニング計画を修正するコーチも おり，筋肉痛はトレーニングにおけるキーワードの一つ となっている.

トレーニングをした数時間後から数日後にかけて生じ る筋肉痛（遅発性筋肉痛）は，運動による筋および結合 組織の損傷が主たる原因であると考えられており, 筋肉 痛, 筋損傷ともに筋収縮のなかでも特に筋への負担が大
きい伸張性収縮後に起こることが報告されている ${ }^{2-6)}$.

このトレーニング後の筋肉痛は, トレーニングで行な う運動の動作を変化させる可能性も考えられる。筋肉痛 により意図せずに運動が変わってしまうのであれば，行 おうとしている動作（振る舞い）とは大きく異なってし まい, マイナスのトレーニング効果をもたらすことも危 惧される。特に強い伸張性筋収縮を伴うプライオメト リックスを計画・実施する際には, 筋肉痛とトレーニン グにおけるパフォーマンスおよび運動中の動作との関係 を把握することの重要性は増す。このような理由で, ト レーニングを考える上で，筋肉痛が運動に及ぼす影響を 考慮にいれることは重要であると考える。

Horita et al. ${ }^{7)}$ は，スレッジを用いたドロップジャンプ 
を疲労困供（100回程度の反復）まで繰り返し， 2 時間 後，2 日後，4日後におけるジャンプパフォーマンス， 下肢の kinetics と kinematics, 筋放電, 血清クレアチン キナーゼ活性などの変化を検討している。この研究では Stretch-Shortening Cycle（SSC）運動後に起こる生体 内扮よび運動に㧍ける変化に関して多くの有益な知見を 得ており，そのうちの一つとして，伸張によって生じる 筋損傷の間接的な指標であるクレアチンキナーゼ活性の 増加率が大きい者ほどジャンプパフォーマンスの低下率 が大きいという結果をあげることができる。この結果か らは, SSC 運動後の筋肉痛がジャンプ運動後のパフォー マンスなどに影響を及ぼしていることを間接的に推察す ることができる。しかしながら，筋肉痛は個人によって 感じ方が違うという報告 ${ }^{8-10)}$ や，一度トレーニングをし た筋は筋肉痛が生じにくく，しかも回復も早いという報 告 ${ }^{4,11-14)}$ があり，主観による筋肉痛の程度と，筋損傷の 程度が比例関係にあるのではないことが分かる，そのた め, 筋肉痛とパフォーマンスや動作などとの直接的な関 係を検討する必要性を感じる。しかし，トレーニング後 の筋肉痛とパフォーマンスや動作の変化との関係を検討 した研究はなく，筋力や可動闇に及ぼす影響を検討した 研究 $2.4,9$ が散在するのみである.

そこで，本研究ではSSCを用いて短時間で大きな力を 発揮するプライオメトリクスの代表的な運動である高強 度のジャンプを対象運動とし, 疲労運動負荷を与えた後 の遅発性筋肉痛, ジャンプのパフォーマンス, 地面をキッ クする力, 下肢動作などの回復過程を明らかにし, 筋肉 痛とパフォーマンスおよび動作の変化などとの関係を検 討した。

\section{方 法}

被検者 これまでにプライオメトリクスの専門的経験が ある体育系の大学院及び大学に所属する男性 9 名を被検

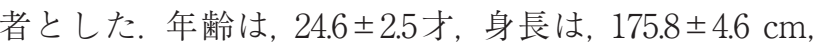
体重は, $71.8 \pm 4.8 \mathrm{~kg}$ であった。被検者には, 研究の趣旨, 研究に伴う苦痛, 研究途中に拀いても研究参加を拒否で きることなどを説明し，書面をもって同意を得た．なお， 本研究は, 筑波大学研究倫理委員会の承認を得て実施した。

本研究では，対照群を設定していないため，実験群の 疲労運動後の筋肉痛，動作等に関するデータのみから回 復過程を検証した。

測定の手順 疲労運動の直前 (Pre)，4 時間後 (P4)，24 時間後 (P24), 72 時間後 (P72) に主観的な筋肉痛の調査, ドロップジャンプのパフォーマンスと接地中の地面反 力，身体重心の移動，下肢の動作などを測定した，それ ぞれの測定前には，傷害の予防を目的としてジョギング $800 \mathrm{~m}$, ストレッチ 5 分程度の共通したウオーミングアッ
プを実施した。ジョギングの強度は，Borg スケール ${ }^{15)}$ の主観的運動強度の 9 点（楽である）に相当する程度を 指示した. ストレッチングは, 下腿後面, 大腿前面・後面, 殿部，背部を対象に，10〜20秒を静的に伸ばす方法を用 いた。

なお，疲労運動 72 時間前から，被検者には筋肉痛が伴 うトレーニングや激しい運動および飲酒を禁じた.また, 疲労運動後から 72 時間後の測定までの間, 一切のトレー ニングや運動および飲酒を禁じた。

疲労運動後の測定を $4 ， 24 ， 72$ 時間後としたのは，以 下の理由による。

(1) 4 時間：一日に 2 回トレーニングを行うケースを想定 した（例：午前と午後).

(2) 24 時間：翌日にトレーニングを行うケースを想定した。

(3) 72 時間：高強度の筋力トレーニング後にトレーニング 前の水準まで回復するには $48-72$ 時間が必要であると いう指摘16)，適当なトレーニング頻度は $2-3$ 回／週 であるという指摘 17,18 から 72 時間後を設定した。

疲労運動 疲労運動は以下の通りである（Fig. 1).

(1) 手は腰で, 台高 $45 \mathrm{~cm}$ からドロップジャンプを行い, 前に置いた台高 $60 \mathrm{~cm}$ の台に跳び乗る. 10 回 × 10 セッ ト．1セットに要する時間は約 30 秒，セット間のレス トは 1 分とした。

(2)手は腰で, 連続 10 回のリバウンドジャンプ (45 cm 程

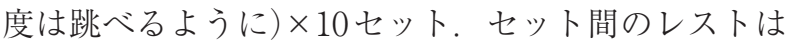
30秒とした。

両方の運動において，接地時間はできるだけ短くし， できるだけ高く跳ぶことを意識して全力で行うように指 示をした。な㧍，疲労運動中の動作に関しては，被検者 間で顕著な差異が生じないように指示を与えた。

測定内容 それぞれの測定のウオーミングアップ後に以 下の内容の調査を実施した。

1) 主観的筋肉痛の調查

本研究では, 筋肉痛の程度を Face Rating Scale (FRS) を参考に 6 段階で表し，感じている痛みがどの言語表現 に近いかを選択する方法を用いた、Visual Analog Scale (VAS) のように感じる痛みを数字で表すのではなく，6 段階の言語表現にすることにより，トレーニング者の感 じている痛みを感覚的に捉えることができ，トレーニン グ現場への応用が円滑になると考えたからである。しか し，これらの 6 段階が等間隔に配置された尺度であるこ とを実証し，提示できないことは本研究の限界である.

以下の質問を行った。

質問 筋肉の痛みを感じますか?

0:まったく感じない $1:$ 少しは感じる

2: やや感じる 3: ある程度感じる 


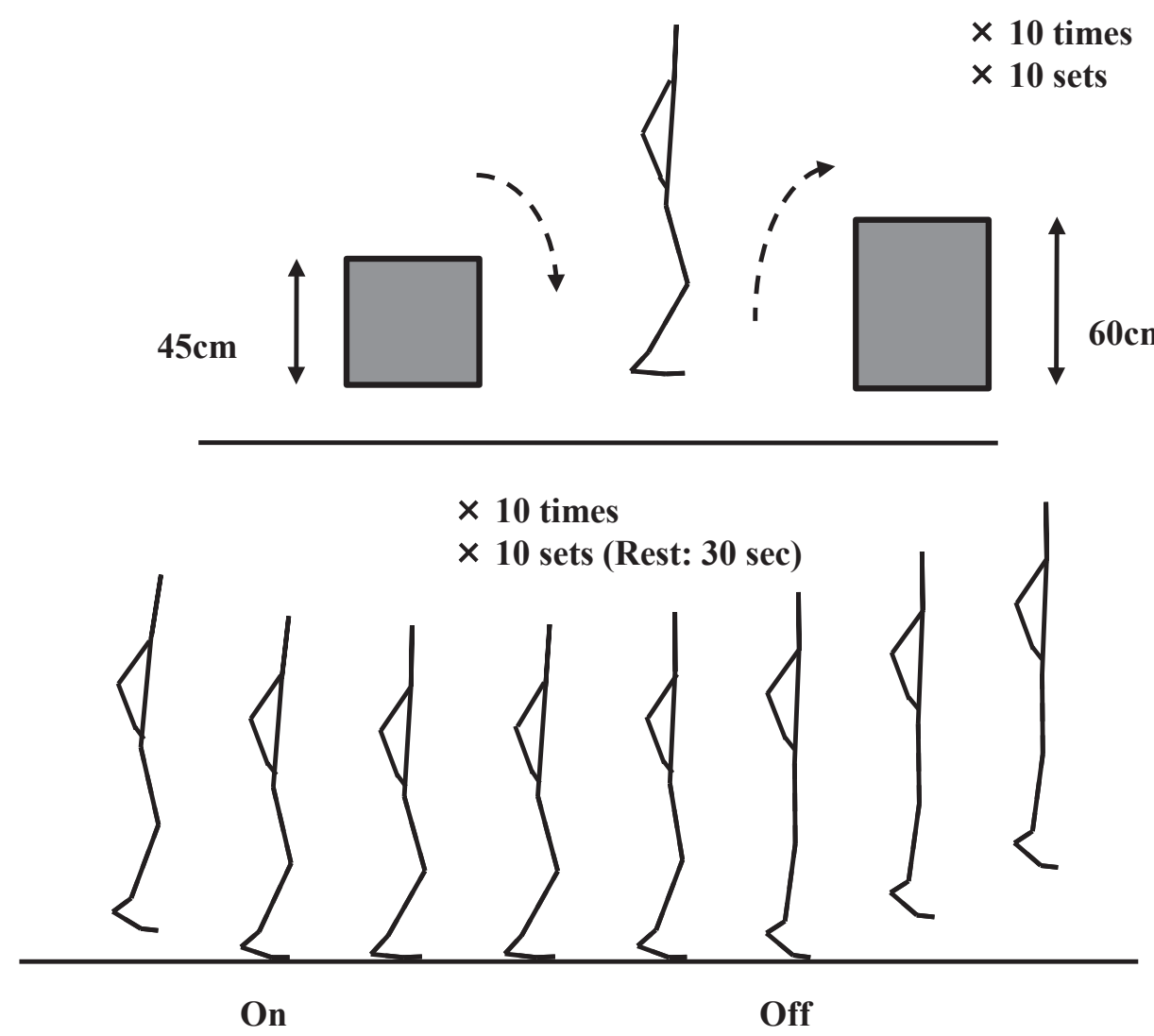

Fig. 1 Explanation of intensive jump exercises.

4:かなり感じる

5: 非常に感じる

\section{2) ドロップジャンプ}

手を腰に当てた姿勢での $30 \mathrm{~cm}$ の台高からのフォース プレート上のドロップジャンプを $2-3$ 回課した。 この とき，台から勢いをつけずにそのまま落下し，「できる だけ短い時間で高く跳ぶ」ように指示した。「落下の際 に台をキックした」と，検者が判断した試技は無効とし た。 また，ジャンプ後のフォースプレートへの着地姿勢 に関しても自然な姿勢を取るように指示をした。この ジャンプ中の姿勢の統制は, ジャンプ運動の指導に熟練 した検者が主観的観察により行ったため完全ではなかっ た可能性があるが，これは本研究の限界である.

ジャンプ中の動作を被検者の側方 $15 \mathrm{~m}$ 地点から 1 台 のハイスピードビデオカメラ（Casio社製, EX-F1）によ り，毎秒 300 コマで撮影した。 なお，被検者の身体23点 (左右下肢のつま先, 母指球, 踵, 外果, 腓骨頭, 大転子. 左右上肢の肩峰突起, 时, 手首, 中手骨. 胸骨上縁, 耳 珠点，頭頂部）に反射マーカを貼着した。同時に，地面 反力をフォースプレート(Kistler 社製, 9281A)を用いて, $1000 \mathrm{~Hz}$ のサンプリング周波数にて測定し, A/D変換し た後, パーソナルコンピュータ (DELL社製, Studio xps 9100）に取込んだ。撮影した画像と地面反力データの同
期のためにライトをカメラに写し込むとともに同期信号 をコンピュータに取込んだ。

データ処理 得られたデータから以下の項目を算出し た. なお，ジャンプ運動中の重心の最下点を基準にして， 下降局面をエキセントリック局面 (Ec 局面)，上昇局面 をコンセントリック局面（Con局面）と定義した.

1）ドロップジャンプのパフォーマンス

地面反力データからドロップジャンプのパフォーマン スとして以下の項目を算出した.

a ) 跳躍高 $(\mathrm{m}): 1 / 8 \times 9.8$ (重力加速度 $) \times$ 滞空時間 $^{2}$

b ) 接地時間 ( $\mathrm{sec})$

c ）ドロップジャンプ・インデックス (DJindex ${ }^{19)}(\mathrm{m} /$ $\mathrm{sec})$ : 跳躍高／接地時間

\section{2 ）接地中の重心低下}

ビデオ動作解析システム（ディケイエイチ社製, FrameDIAS・Ver.2 for Windows) を用いて, 毎秒 100 フレー ムで全身 23 点と較正マーク 4 点の 2 次元座標を計測し た。分析区間は, 接地 10 フレーム前から離地後10フレー ムとした。画像から読み取った身体各部の座標は，実長 換算の後に, バタワース型テジタルフィルタ20)を用いて, 4-9 Hzで平滑化した。 なお, 身体重心の算出には阿江 ${ }^{21)}$ 
の身体部分慣性係数を用いた.

重心に関する変数として, Ec 局面での重心低下量（以 後，重心低下量）（m）を算出した。

\section{3 ）接地中の下肢三関節の角度変化}

$\mathrm{Ec} \cdot \mathrm{Con}$ 局面での足関節および膝関節，接地局面の股 関節の角度変化量（deg）を算出した。屈曲をマイナス, 伸展をプラスとした。各関節角は以下の通り定義した。

- 足関節角：下腿（果点と膝関節中心を結ぶ線分）と 足（母子球と踵を結ぶ線分）がなす角。

- 膝関節角：下腿と大腿（大転子と膝関節中心を結ぶ 線分）がなす角.

- 股関節角：体幹（胸骨上縁と両大転子の中点を結ぶ 線分）と大腿がなす角.

\section{4 ）地面反力}

接地中の垂直方向への平均地面反力の体重比（以下， 反力とする) $(\mathrm{N} / \mathrm{kg}$ ), 接地中の力積の体重比（以下, 力 積とする）（N・s/ $\mathrm{kg} ）$ を算出した.

1 ）～4 ) であげた変数は，Preから P4，P24，P72へ の変化率（例：P4への変化率 $=\mathrm{P} 4 /$ Pre）を算出した。

統計 Pre, P4, P24, P72の測定項目間の有意差検定に は対応のある一元配置の分散分析を用い，F值が有意で あった項目については多重比較を行った。分析項目間の 関係を調べるのにピアソンの相関係数を算出した。いず れも有意性は，危険率５\%未満で判定した。

\section{結果}

Table 1は, 筋肉痛, DJindex, 跳躍高, 接地時間, 重 心低下量, 下肢三関節の動作範囲, 反力, 力積などの経 時的変化を示している，筋肉痛のレベルはP4, P24, P72 がPreよりも高く, P24がP4およびP72よりも高い值を 示した. DJindexは, P4とP24がPreとP72よりも有意 に小さかった。跳躍高は，P24がPre，P72よりも有意 に小さく，接地時間と重心低下量は，逆にP24がPre, P72よりも有意に大きかった。動作範囲では，足関節と 膝関節の $\mathrm{Ec}$ 局面に有意差が認められており，足関節で は, P4, P24がPreよりも有意に大きく, 膝関節では P24 がPreよりも有意に大きくなっていた， 反力は，P4 と P24がPreとP72よりも有意に小さかった。

Table 2は, PreのDJindex, 跳躍高, 接地時間, 重 心低下量, 反力, 力積の間の相関係数を示している. DJindexは，構成要素のうち跳躍高と高い正の相関関係 にあった $(\mathrm{r}=0.926, \mathrm{p}<0.001)$ 。また, DJindex, 跳躍高 は力積との間に有意な正の相関関係を示した $(r=0.706$, $\mathrm{p}<0.05 ; \mathrm{r}=0.841, \mathrm{p}<0.01)$.

Table 3は, P4, P24, P72での筋肉痛のレベル，それ
ぞれの測定項目のPreから P4, P24, P72への変化率の 間での相関係数を示したものである。P 4 では，筋肉痛 はDJindex $(\mathrm{r}=-0.672, \mathrm{p}<0.05)$, 跳躍高 $(\mathrm{r}=-0.865$, $\mathrm{p}<0.01 ） と の$ 間に負の相関関係が，DJindexは跳躍高 $(\mathrm{r}=0.818, \mathrm{p}<0.01)$ と反力 $(\mathrm{r}=0.799, \mathrm{p}<0.01)$ との間に 正の相関関係が，跳躍高は力積 $(r=0.759, \mathrm{p}<0.05)$ と の間に，接地時間は重心低下量 $(r=0.751, p<0.05)$ と の間にそれぞれ有意な正の相関関係が認められた。 P24 では，筋肉痛と測定項目との間には有意な相関関係は 認められなかった。 DJindexは，接地時間（ $\mathrm{r}=-0.867$, $\mathrm{p}<0.01 ）$ との間に有意な負の相関関係が，重心低下量 $(\mathrm{r}=-0.714, \mathrm{p}<0.05)$, 反力 $(\mathrm{r}=0.960, \mathrm{p}<0.001)$ との間 に有意な正の相関関係が，接地時間は，反力 $(r=-0.820$, $\mathrm{p}<0.01)$ との間に有意な負の相関関係が, 力積 $(r=0.791$, $\mathrm{p}<0.01 ） と の$ 間に有意な正の相関関係が認められた。重 心低下量は反力 $(r=-0.770, p<0.05)$ との間に有意な負 の相関関係が認められた。 P72でも筋肉痛と測定項目と の間には有意な相関関係は認められなかった. DJindex は，重心低下量 $(r=-0.776, p<0.05)$ との間に有意な負 の相関関係が，反力 $(r=0.822, p<0.01)$ との間に有意な 正の相関関係が, 跳躍高は力積 $(\mathrm{r}=0.677, \mathrm{p}<0.05)$ との 間に有意な正の相関関係が, 接地時間は, 反力 $(r=-0.772$, $\mathrm{p}<0.05)$ との間に有意な負の相関関係が, 力積 $(r=0.783$, $\mathrm{p}<0.01)$ との間に有意な正の相関関係が認められた

Fig. 2 は, Table 3 の項目のうち, P4, P24, P72での筋 肉痛の程度, ジャンプパフォーマンスに関する測定項目 のPreから P4，P24，P72への変化率の間での関係をグ ラフで示したものである。

\section{考察}

筋肉痛は, P24の4.1 1.4 「かなり感じる」程度をピー クに, P72では $2.1 \pm 1.3$ と4を下回る「やや感じる」程 度のレベルまで低下した. DJindex, 跳躍高, 接地時間と もに, P24で変化が最も大きく, P72にはほぼPre近くの 水準まで回復をしていた。

4 時間後の変化 P4では跳躍高, 接地時間ともに有意で はないが，明らかな変化を示しており，この二変数から 算出したDJindexは，Preに比較して有意な低下を示し ている。 また反力は低下しており，キックする力は弱く なったことがわかる，P4は，堀田 ${ }^{22)}$ の言う，発揮する力 の減少を踏切時間の延長で補償し, 一定の跳躍高を保持 している段階であると考えられる。動作面ではEc局面 での足関節の屈曲が大きくなっていることから，接地の 衝撃に足関節が耐えることができずに，足関節で緩衝し てしまうような接地動作になったものと推測できる。堀 田 $^{22)}$, Horita et $\mathrm{al}^{23)}$ は, 高強度のジャンプ運動の繰り 返しにより生じた中枢神経性，末梢神経性および筋性の 
Table 1. Comparisons of muscle soreness, change ratio of jump performances, kinetic and kinematic variables before intensive jump exercise (Pre), 4 hours (P4), 24 hours (P24) and 72 hours (P72) after intensive jump exercise.

\begin{tabular}{|c|c|c|c|c|c|c|}
\hline Variables & Pre & Post 4 & Post 24 & Post 72 & $\begin{array}{l}\text { Variace } \\
\text { analysis }\end{array}$ & Multiple comparison \\
\hline Muscle soreness & $0 \pm 0$ & $2.78 \pm 1.39$ & $4.11 \pm 1.36$ & $2.11 \pm 1.27$ & $* * *$ & Pre $<$ P $4 \cdot \mathrm{P} 24 \cdot \mathrm{P} 72, \mathrm{P} 4 \cdot \mathrm{P} 72<\mathrm{P} 24$ \\
\hline Drop jump index $(\mathrm{m} / \mathrm{s})$ & $2.772 \pm 0.326$ & $2.446 \pm 0.252$ & $2.271 \pm 0.200$ & $2.679 \pm 0.456$ & $* * *$ & Pre $\cdot \mathrm{P} 72>\mathrm{P} 4 \cdot \mathrm{P} 24$ \\
\hline Jump height $(\mathrm{m})$ & $0.420 \pm 0.047$ & $0.399 \pm 0.057$ & $0.386 \pm 0.041$ & $0.409 \pm 0.053$ & $*$ & Pre $\cdot \mathrm{P} 72>\mathrm{P} 24$ \\
\hline Contact time ( $\mathrm{s}$ ) & $0.152 \pm 0.007$ & $0.163 \pm 0.011$ & $0.171 \pm 0.024$ & $0.154 \pm 0.014$ & $*$ & Pre $\cdot \mathrm{P} 72<\mathrm{P} 24$ \\
\hline CG decrease $(\mathrm{m})$ & $0.059 \pm 0.009$ & $0.070 \pm 0.017$ & $0.081 \pm 0.017$ & $0.067 \pm 0.014$ & $*$ & Pre $\cdot \mathrm{P} 72<\mathrm{P} 24$ \\
\hline \multicolumn{7}{|c|}{ Range of joint novement (deg) } \\
\hline Ankle flexion & $14.0 \pm 3.2$ & $17.3 \pm 5.9$ & $18.4 \pm 4.6$ & $15.9 \pm 3.9$ & $*$ & Pre $<$ P $4 \cdot \mathrm{P} 24$ \\
\hline Ankle extension & $55.6 \pm 7.4$ & $53.9 \pm 4.4$ & $52.3 \pm 5.5$ & $50.5 \pm 6.2$ & & \\
\hline Knee flexion & $3.9 \pm 3.0$ & $7.7 \pm 4.3$ & $10.7 \pm 7.2$ & $6.4 \pm 6.3$ & $*$ & Pre $<$ P24 \\
\hline Knee extension & $42.3 \pm 4.0$ & $42.4 \pm 5.0$ & $42.2 \pm 9.2$ & $41.0 \pm 1.7$ & & \\
\hline Hip & $29.3 \pm 4.9$ & $30.3 \pm 6.1$ & $27.3 \pm 7.2$ & $29.6 \pm 7.9$ & & \\
\hline Mean force $(\mathrm{N} / \mathrm{kg})$ & $40.6 \pm 2.3$ & $37.7 \pm 2.2$ & $36.5 \pm 3.0$ & $40.0 \pm 2.3$ & $* * *$ & Pre $\cdot$ P72>P4 $\cdot$ P24 \\
\hline Impulse $(\mathrm{N} \cdot \mathrm{s} / \mathrm{kg})$ & $6.17 \pm 0.19$ & $6.15 \pm 0.32$ & $6.24 \pm 0.32$ & $6.16 \pm 0.22$ & & \\
\hline
\end{tabular}

${ }_{* * *} \mathrm{p}<0.001{ }^{* *} \mathrm{p}<0.01{ }^{*} \mathrm{p}<0.05<\mathrm{p}<0.05$

Table 2. Correlation coefficients between jump performances, kinetics and kinematics before intensive jump exercise.

\begin{tabular}{|c|c|c|c|c|c|}
\hline Variables & 1) & 2) & 3) & 4) & 5) \\
\hline 1) Drop jump index & - & & & & \\
\hline 2) Jump height & $0.926 * * *$ & - & & & \\
\hline 3) Contact time & -0.260 & 0.112 & - & & \\
\hline 4) CG decrease & -0.159 & 0.065 & 0.465 & - & \\
\hline 5) Mean force & 0.561 & 0.412 & -0.563 & -0.222 & - \\
\hline 6) Impulse & $0.706 *$ & $0.841 * *$ & 0.189 & 0.323 & 0.410 \\
\hline
\end{tabular}

${ }^{* * *} \mathrm{p}<0.001{ }^{* *} \mathrm{p}<0.01{ }^{*} \mathrm{p}<0.05$

筋疲労 ${ }^{24)}$ の影響は, 動作前のプリプログラムの段階で生 じており，更なる筋損傷を防ぐために中枢が動作に抑制 をかけていると指摘しており, P4でみられた接地直後 の足関節の緩衝は,この制御の結果であると解釈できる. このような緩衝動作が，SSC運動の効率を悪くし，キッ ク力の低下につながったものと考えられる。

また, Fig. 2が示すようにP4では筋肉痛を強く感じて いる者ほど跳躍高の低下が著しくなり，その結果, DJindex も低くなったことが分かる，このグラフから筋肉痛 レベル 4，5の者は跳躍高が大きく低下していることが 明らかである，筋肉痛が生じると反射活動（伸張反射） が減少するのか ${ }^{222}$ ，あるいは強い痛みを伝える筋肉から の情報が中枢に対して抑制的に作用し，結果として中枢 で運動の抑制が生じるのか ${ }^{25)}$ は, 本研究の結果から明ら かにできないが, 筋肉痛の感じ方はトレーニングを実施 する上で貴重な指標になり得ると考えられる。具体的に は, 筋肉痛の著しい者（レベル 4, 5 が目安）は, 跳躍高 が低くなり，「短い時間で高く跳ぶ」というドロップジャ ンプの課題を達成できないということである.
P4に损けるこれらの結果からは, 以下のような示唆 が得られる。例えば午前中のセッションでジャンプエク ササイズを実施したとすると, 午後のトレーニングで, 「ある程度痛みを感じる」という比較的軽度の筋肉痛の 状態であっても，再びジャンプエクササイズを行う場合 には，下肢動作が変容する可能性があることを考慮に入 れる必要がある。

24 時間後の変化 筋肉痛が最も強かったP24では有意 な跳躍高の低下および接地時間の増大がみられ, その結 果, DJindexは顕著な低下を示した。すなわち P24では, 「短時間で高く跳ぶ」というプライオメトリックジャン プの課題が達成できない状況に陥っていたことが分か る。このパフォーマンスの低下は, Ec 局面での膝関節お よび足関節の屈曲が有意に大きかったこと, その結果, 重心低下量が大きくなったことなどの踏切中の動作の変 化と関係がある。

上述の下肢関節角度, 重心高に関する変化は, 接地時 間を長くし踏切中の力積を少しでも大きくすることで跳 
Table 3. Correlation coefficients between the change rate of muscle soreness, change ratio of jump performances, kinetics and kinematics at post 4, 24 and 72 hours.

\section{POST 4}

\begin{tabular}{|c|c|c|c|c|c|c|}
\hline Variables & 1) & 2) & 3) & 4) & 5) & $6)$ \\
\hline 1) Muscle soreness & - & & & & & \\
\hline 2) Dop jump index & $-0.672 *$ & - & & & & \\
\hline 3) Jump height & $-0.865 * *$ & $0.818 * *$ & - & & & \\
\hline 4) Contact time & -0.214 & -0.403 & 0.197 & - & & \\
\hline 5) CG decrease & 0.001 & -0.400 & 0.038 & $0.751 *$ & - & \\
\hline 6) Mean force & -0.268 & $0.799 * *$ & 0.506 & -0.542 & -0.651 & - \\
\hline 7) Impulse & -0.640 & 0.415 & $0.759 *$ & 0.516 & 0.407 & 0.202 \\
\hline
\end{tabular}

\section{POST 24}

\begin{tabular}{|c|c|c|c|c|c|c|}
\hline Variables & 1) & 2) & 3) & 4) & 5) & 6) \\
\hline 1) Muscle soreness & - & & & & & \\
\hline 2) Dop jump index & -0.033 & - & & & & \\
\hline 3) Jump height & -0.620 & 0.455 & - & & & \\
\hline 4) Contact time & -0.235 & $-0.867 * *$ & 0.037 & - & & \\
\hline 5) CG decrease & 0.196 & $-0.714 *$ & -0.396 & 0.567 & - & \\
\hline 6) Mean force & -0.190 & $0.960 * * *$ & 0.492 & $-0.820 * *$ & $-0.770 *$ & - \\
\hline 7) Impulse & -0.656 & -0.477 & 0.509 & $0.791 * *$ & 0.339 & -0.376 \\
\hline
\end{tabular}

\section{POST 72}

\begin{tabular}{lllllll}
\hline \multicolumn{1}{c}{ Variables } & $1)$ & \multicolumn{1}{c}{ 2) } & 3) & 4) & 5) \\
\hline 1) Muscle soreness & - & & & & & \\
2) Dop jump index & -0.106 & - & & & & \\
3) Jump height & 0.258 & 0.615 & - & & & \\
4) Contact time & 0.364 & -0.625 & 0.228 & - & & \\
5) CG decrease & 0.180 & $-0.776 *$ & -0.329 & 0.614 & - & - \\
6) Mean force & -0.395 & $0.822 * *$ & 0.235 & $-0.772 *$ & $-0.932 * * *$ & - \\
7) Impulse & 0.224 & -0.091 & $0.677 *$ & $0.783 * *$ & 0.121 & -0.262 \\
\hline
\end{tabular}

\section{$--\cdot$ RJ-index $\longrightarrow \Delta$ Jump height}

Post 4

$1.4[y=-0.060 x+1.117$

$r=0.865$

$1.2-p<0.01$

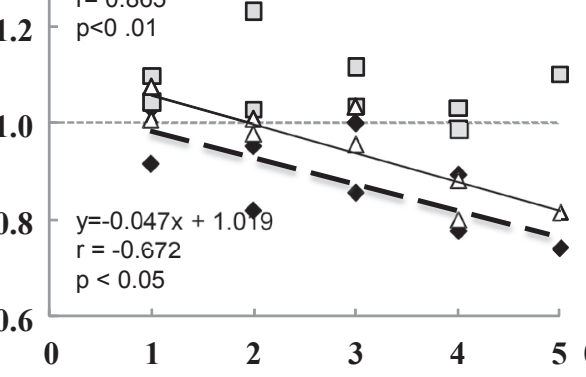

$\square$ Contact time

Post 24

Post 72

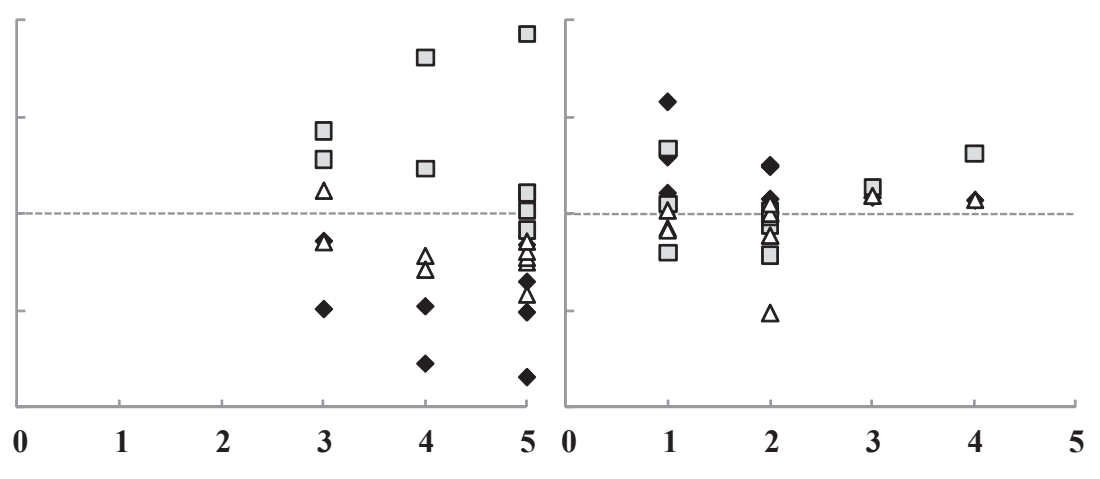

Level of Muscle soreness

Fig. 2 Relationship between the level of muscle soreness and the change ratio of jump performance. 
躍高を獲得しようとする身体の制御機構に関係するもの と解釈できる，実際に反力が有意に減少したのにもかか わらず，接地時間が増大したことから力積はPreのレベ ルを維持して跳躍高を獲得するように制御されている. 堀田 ${ }^{22}$ は, 100 回連続ジャンプ運動の後半10回の試技を 前半の 10 回の試技と比較すると, 後半は地面反力 (発揮 張力）が支持期にわたり低值で推移し, 踏切時間が増大 していたことから, 後半試技では発揮張力の減少を踏切 時間の延長で補償し, 一定の総仕事量すなわち跳躍高を 保持していたことを報告している。 また動作面でも接地 期後半の足関節可動域の減少を膝関節可動域の増大で 補償していることを明らかにしている. Arampatzis et $\mathrm{al}^{26)}$ は，ドロップジャンプに扔いて最も大きなパワーを 発揮するためには，下肢のばね的な動きをより“硬い” ものにすることが重要ではなく，下肢全体が最も大きな パワーを発揮できるように下肢のばね的な動きを調節す ることが重要であると指摘しており，本研究で示された 跳躍高を獲得するための “接地時間を長くし踏切中の力 積を少しでも大きくする”という補償作用のための変容 がこれに一致すると考えられる。そして，その後，神経 性拧よび筋性の筋疲労 ${ }^{24)}$ がさらに進行してくるとこのよ うな制御でのパフォーマンス維持が困難になるとされて いる ${ }^{22)}$. 本研究のP 24 の状態は, 補償できる範囲を超え た状態に匹敵するものであると推測できる。また，跳躍 運動の繰り返しにより伸張反射機能が低下すること ${ }^{27)}$ 報告されており, 上述の補償は, SSCの機能低下を導き, プライオメトリックジャンプの狙いや課題とそぐわなく なったと考えられる。

P24においては，DJindexは全員が100\%を下回ってお り,その構成要素である跳躍高は 1 名を除いては低下し, 接地時間も 1 名を除いて長くなった。そして, DJindex が低下した者ほど, 接地時間が長くなっていた。このジャ ンプの質を表す指標であるDJindexは, 重心低下量およ び反力の変化と有意な関係を示し, また重心低下量拈よ び反力の変化率は相互に有意な関倸を示した。これらの 一連の関係を解棌すると，P24では重心の低下が著しい 者ほど接地時間が長くなるとともに，接地でのキック力 が低下し, ジャンプの課題である “短い時間で高く跳ぶ” という課題の達成から遠ざかったということになる。

24 時間後には, このようなパフォーマンスや動きの質 に扮ける大きな変化が認められることから, 高強度の ジャンプエクササイズを実施した翌日の「筋肉痛をかな り感じる」といったような状態でジャンプエクササイズ を行えば，プライオメトリックスの課題を遂行すること は不可能であると考えられる。また，P24では，多くの 被検者が筋肉痛の高いレベルに集中しているため, 筋肉 痛の感じ方と, パフォーマンス低下の程度との間の関係 は検証することはできなかった。
72 時間後の変化 P72では, 筋肉痛はレベル 2 の「少し 感じる」程度残っている。しかし，パフォーマンスは, いずれもPreとの間には差はなく，ほぼ回復しているも のと考えられる。 また，力積，動作範囲などP24では有 意に変化していた項目もPreに近いレベルまで回復して いる.このことから, 筋肉痛とパフォーマンスの回復は, 完全には一致していないものと考えられる.

また，Fig. 2からは，P72では，Preの水準を示す1を 上回る者抒よび 1 前後の者を合わせると, DJindexでは 6 名, そのうちの 3 名は 1.1 を超える変化率を示している ことがわかる。すすおち, P72では, 「短い時間で高く跳ぶ」 というプライオメトリックジャンプの課題を遂行するに あたって, 回復あるいは超回復を迎えている者が半数以 上いたことがわかる。これらの結果から高強度ジャンプ エクササイズ後, 間隔を 2 日おいて再び同エクササイズ を実施することは，パフォーマンス拉よび動作の面から 検討しても妥当であると判断できる。 これは，プライオ メトリックジャンプ後にトレーニング前の水準まで回復 するには 48 72 時間が必要であるという指摘 ${ }^{16)}$, 適当な トレーニング頻度は $2-3$ 回／週であるという指摘17,18) は，適切であることを支持するものであり，超回復の原 理 ${ }^{28)}$ の応用にとって有益な知見となる.

筋肉痛が交絡因子である可能性や，筋肉痛とジャンプ パフォーマンスを表す各変数との因果関係等を検討する ためには多変量解析を用いることが必要となる。しかし ながら本研究の被検者数が 9 名であるために相関係数を もとに考察を進めたことは，本研究の限界である。

また, 本研究では単発のトレーニングの回復過程につ いて検証をしたが，一度トレーニングをした筋は筋肉痛 が生じにくく，しかも回復も早いという報告 ${ }^{4,11-14)}$ があ ることからも，実際のトレーニング現場で展開されてい るトレーニングが反復された場合の回復過程に関しても 今後, 検証する必要がある。

\section{結 語}

本研究では高強度のプライオメトリックジャンプ遂行 後の遅発性筋肉痛, ジャンプのパフォーマンス, キック 力, 下肢動作などの回復過程と, 筋肉痛とパフォーマン ス㧍よび動作などとの関係を検討した。その結果，ジャ ンプのパフォーマンスは, 筋肉痛の程度と関係があるこ とが明らかになった．特に筋肉痛の顕著な疲労運動の 24 時間後では，有意な跳躍高の低下および接地時間の増大 がみられ，その結果，DJindexは顕著な低下を示した。 このことから，「短時間で高く跳ぶ」というプライオメ トリックジャンプの課題が達成できない状況に陥ってい たことが分かった。このパフォーマンスの低下は，エキ セントリック局面での膝関節および足関節の動作の変 化，地面反力の低下などと関係があった。また，4 時間 
後では筋肉痛を強く感じている者ほど跳躍高の低下が著 しくなり, その結果, DJindex も低くなっていた. そして, 72 時間後では,「やや痛い」程度の筋肉痛が残っているが, DJindex および跳躍高で運動前とほほ同等の水準まで回 復をしていることから，「短い時間で高く跳ぶ」という プライオメトリックジャンプの課題を遂行するにあたっ て回復を迎えていることが考えられる。これらの知見か らトレーニングを計画・実施するうえで筋肉痛を考慮に 入れることは有効であることが明らかになった。

\section{文献}

1）野坂和則. 筋肉を肥大させるためには筋を損傷させると よいのか?, 征矢英昭・本山 貢 - 石井好二郎編, これで なっとく使えるスポーツサイエンス, 講談社, 東京, 1314, 2002.

2) Ebbeling CB, Clarkson PM. Exercise-induced muscle damage and adaptation. Sports Med 7: 207-234, 1989.

3) Clerk MJ, Eston EG. Delayed onset muscle soreness: mechanisms and management. J Sports Sci 10: 325341, 1992

4) Clarkson PM, Nosaka K, Braun B. Muscle function after exercise induced muscle damage and rapid adaptation. Med Sci Sports Exerc 24: 512-520, 1992.

5) MaIntype DL, Reid WD, McKenzie DC. Delayed muscle soreness the inflammatory response to muscle injury and its clinical implications. Sports Med 20: 2440, 1995.

6) Brooks SV, Zerba E, Faulkner JA. Injury to muscle fibers after single stretches of passive and maximally stimulated muscles in mice. J Physiol 488: 459-469, 1995.

7) Horita T, Komi PV, Nicol C, Kyröläinen H. Stretch shortening cycle fatigue: interactions among joint stiffness, reflex, and muscle mechanical performance in the drop jump corrected. Eur J Appl Physiol 73: 393403, 1996.

8) Rodenburg JB, Bar PR, De Boer RW. Relationship between muscle soreness and biochemical and functional outcomes of eccentric exercise. J Appl Phyiol 74: 2976-2983, 1993

9) Warren GL, Lower DA, Armstrong RB. Measurement tools used in the study of eccentric contraction-induced injury. Sports Med 27: 43-59, 1999.

10) Nosaka K, Newton N. Repeated eccentric exercise bout do not exacerbate muscle damage and repair. J Str Cond Res 16: 117-122, 2000.

11) Foley JM, Jayaraman RC, Prior BM, Pivarnik JM, Meyer RA. MR measurements of muscle damage and adaptation after eccentric exercise. J Appl Physiol 87:
2311-2318, 1999

12) Nosaka K, Sakamoto K, Newton N, Sacco P. The protective effect of reduced-load eccentric exercise on muscle damage of the elbow flexors. Eur J Appl Physiol 85: 34-40, 2001.

13) Nosaka K, Newton N, Sacco P. How long does the protective effect on eccentric exercise-induced muscle damage last? Med Sci Sports Exerc 33: 22-29, 2001.

14) Nosaka K, Newton N. Concentric or eccentric training effect on eccentric exercise- induced muscle damage. Med Sci Sports Exer 34: 63-69, 2002.

15) Borg G. Perceived exertion as an indicator of somatic stress. Scandinavian J Rehabilitation Med 2: 92-98, 1970.

16) Bompa TO. PERIODIZATION OF STRENGTH. VERITAS PUBLISHING. INC, Tronto, 218-219, 1994.

17) Aaberg E. Resistance Training Instruction. Human Kinetics, Champaign, 54, 1999 .

18）有賀誠司. プライオメトリクス, ストレングス\&コン ディショニング I, NSCA ジャパン編, 大修館書店, 東京, 108-116, 2003

19）図子浩二, 古藤高良, 高松 薰: 各種スポーツ選手におけ る下肢の筋力およびパワー発揮に関する特性, 体育学研 究, 38: 265-278, 1993.

20) Wells RP, Winter DA. Assessment of signal and noise in the kinematics of normal, pathological and sporting gaits. Human Locomotion 1: 92-93, 1980.

21）阿江通良：日本人幼少年およびアスリートの身体部分 係数, Jpn J Sports Sci 15: 155-162, 1996.

22）堀田朋基：伸張から短縮への繰り返しジャンプによる 疲労の影響, 体育の科学, 50: 452-458, 2000。

23) Horita T, Komi PV, Nicol C, Kyröläinen H. Effect of exhausting stretch-shortening cycle exercise on the time course of mechanical behavior in the drop jump: possible role of muscle damage. Eur J Appl Physiol 79: 160-167, 1999.

24）片山憲史, 田中忠蔵, 西川弘恭, 平澤泰介：疲労, 体力科 学, 43: 309-317, 1994.

25) Amussen E, Martin B. A central nervous component in local muscular fatigue. Eur J Appl Physiol 38: 9-15, 1978.

26) Arampatzis A, Schade F, Walsh M, Brüggemann GP. Influence of leg stiffness and its effect on myodynamic jumping performance. J Electromyogr Kinesiol 11: 355364, 2001

27) Nicol C, Komi PV, Horita T, Kyröläinen H, Takala TE. Reduced stretch-reflex sensitivity after exhausting stretch-shortening cycle. Exerc Eur J Appl Physiol Occup Physiol 72: 401-409, 1996.

28) Yakovlev NN. Biochemistry of sport in the Soviet Union: beginning development and present status. Med Sci Sports 7: 237-247, 1975. 